\title{
Direct counting and detection of living Salmonella in biological fluid
}

Takayuki Ezaki, Kenji Hirose, Li-Cheng Zhao, Khan Abdul Quayum, Masaki Miyake, Yoshiaki Kawamura

\begin{abstract}
Abstrak
Untuk mengembangkan metoda cepat untuk menghitung Salmonella hidup dalam cairan biologis, 4 metoda deteksi yang berbeda telah dievaluasi. Metode Flow Cytometric baru yang dapat menghitung partikel lebih besar dari 0,25 mikrometer, telah berhasil diterapkan untuk menghitung bakteri hidup dengan cepat. Metoda ini dapat digunakan bila jumlah sel lebih dari 5000 cfu/ml. Metoda ini juga mampu membedakan populasi bakteri hidup dan mati dalam cairan dalam waktu 30 menit. Untuk dapat secara efektif menemukan bakteri dengan mikroskop, metoda penghitung dengan laser scanning microscopy memerlukan konsentrasi bakteri yang tinggi, lebih besar dari $10^{6} / \mathrm{ml}$. Laser scanning microscopy juga digunakan untuk menganalisis populasi berbeda dalam biakan tunggal. Sel S. typhi terpisahkan dalam dua populasi berbeda setelah dibiakkan 8 jam dalam kaldu LB, sedangkan sel S. typhimurium masih tetap dalam bentuk tunggal meskipun telah 24 jam dibiakkan. Perbedaan populasi sel dari satu galur ini dengan mudah terlihat dengan metoda ini. Kamera photon counting VIM merupakan alat yang paling sensitif, tetapi adanya reduksi dari latar belakang merupakan masalah yang terberat untuk aplikasi alat ini bagi sampel klinis. Metoda PCR kuantitatif juga dipergunakan untuk menghitung jumlah bakteri. PCR dengan metoda siklus cepat dengan menggunakan sekuens Vi, flagela dan rfb dapat mendeteksi organisme dengan jumlah 20-100 cfu/ml. Selama dilakukan proses amplifikasi, amplikon dimonitor secara sekuensial dengan fluoresensi dan hasilnya dapat diperoleh dalam waktu 20 menit.
\end{abstract}

\section{Abstract}

To establish rapid counting methods of living Salmonella in biological fluids, 4 different detection methods were evaluated. A new flow cytometer able to count particles bigger than 0.25 micromiter, was successfully applied for rapid viable bacterial counting. When cell numbers were bigger than $5000 \mathrm{cfu} / \mathrm{ml}$, this method worked. The method was also able to differentiate living and dead bacterial population in fluid within 30 min. Laser scanning microscopic counting method needed high concentration of bacteria more than $10^{6} / \mathrm{ml}^{2}$ to effectively find bacteria under a microscope. The laser scanning microscopy was also used to analyze different population within a single culture. $S$. typhi cells were separated into two different populations after $8 \mathrm{hr}$ culture in LB broth but cells of $S$. typhimurium remained uniform even after $24 \mathrm{hr}$ culture. This difference of cell population in a single strain was easily visualized by this method. Photon counting VIM camera was most sensitive but reduction of background was biggest problems for actual application for clinical samples. Quantitative PCR was also applied for bacterial counting. Rapid cycling PCR prepared from Vi, flagella, and rfb sequences could detect organisms around 20-100 cfuml. During amplification process, amplicon was sequentially monitored by fluorescence and the result was obtained within $20 \mathrm{~min}$.

\section{INTRODUCTION}

Many approaches to count pathogenic bacteria in clinical material had been developed through out the history of microbiology. Among them, quantitative culture on a agar plate was used as a gold standard for this purpose. However, this method have several disadvantages. Culture method takes at least one day to make countable colonies. Some fastidious bacteria cannot grow on laboratory media and thus, colony count does not correlate to the actual bacterial numbers in clinical specimens. To overcome these disad-

Dept. Microbiology, Gifu Univ., School of Medicine, 40

Tsukasa, Gifu 500 Japan vantages, we attempted to count pathogenic bacteria in biological fluid. Flowcytometric counting, laser scanning counting, counting by photon counting ultra-sensitive VIM camera, and counting by rapid cycling PCR method.

\section{MATERIALS AND METHODS}

\section{Bacterial strains}

Salmonella typhi GIFU10007 and Salmonella typhimurium GIFU 12142 strains were cultured in Luria Broth or M9 cysteine broth and incubated for different incubation time and used for counting. All preparation were serially diluted and cultured on heart infusion agar plates to confirm viable cell numbers. 


\section{Flowcytometric counting}

Culture broth was serially diluted with saline and $10^{5} \mathrm{cfu} / \mathrm{ml}$ cell suspension was prepared. The suspension was stained with Bact-Live and Dead cell staining reagent (Molecular Probes). After 30 min staining, the suspension was directly applied to a flowcytometer (Win-Bryte, Bio-Rad). In case, Texas red labeled rabbit anti-Vi antibody was mixed with $S$. typhi and then stained with Bact-Live cell staining reagent.

\section{Laser scanning microscopic counting}

Overnight culture broth were serially diluted with saline and stained with live and dead fluorescence reagent (molecular probes) for $15 \mathrm{~min}$ and the mixture was placed on a slide glass and sealed with cover glass. Fluorescent pictures were collected through BioRad confocal laser scanning microscopy within $30 \mathrm{~min}$ after staining. Pictures were taken by the magnification of $200 \mathrm{x}$ and were processed by MacScope software (Mitani, cop. Japan) to count living particles.

\section{Photon camera counting}

Ultrasensitive single photon counting camera, VIM camera (Hamamatsu Photo, Hamamatsu, Japan) was used to count single cells. Bacteria were first mixed with alkaline-labeled anti-Vi and filtered on HATF Millipore filter membrane. After washing with saline several times, the substrate ASPD was added to the membrane and the filter was immediately placed under VIM camera to count photons.

\section{Counting by Rapid Cycles}

Table 1. Detection of major $\mathrm{rfb}$ gene of Salmonella serovar

\begin{tabular}{|c|c|c|c|c|c|}
\hline Group & Serovar & $O$ antigen & $\begin{array}{c}\mathrm{rfb} E \\
\mathrm{O} 9\end{array}$ & $\begin{array}{c}\mathrm{rfb} \text { PCR } \\
\mathrm{rfb} \text { S(D) } \\
\mathrm{O} 2 \mathrm{a}\end{array}$ & $\begin{array}{c}\mathrm{rfb} J(\mathrm{~B}) \\
\mathrm{O} 4 \mathrm{a}\end{array}$ \\
\hline $\mathrm{A}(\mathrm{O} 2)$ & Paratyphi A & $1,2,12$ & $\mathrm{P} *$ & + & - \\
\hline \multirow[t]{2}{*}{$\mathrm{B}(\mathrm{O} 4)$} & Schottmuellei & $1,4,[5], 12$ & - & - & + \\
\hline & Typhimurium & $1,4,12$ & - & - & + \\
\hline \multirow[t]{2}{*}{$\mathrm{Cl}(06,7)$} & Paratyphi C & $6,7,[\mathrm{Vi}]$ & - & - & - \\
\hline & Choleraesuis & 6,7 & - & - & - \\
\hline $\mathrm{C} 2(06,8)$ & Newport & 6,8 & - & - & - \\
\hline \multirow[t]{3}{*}{$\mathrm{D} 1(09,12)$} & Typhi & $9,12,[\mathrm{Vi}]$ & + & + & - \\
\hline & Enteritidis & 1), 9,12 & + & + & - \\
\hline & Dublin & 1), $9,12,[\mathrm{Vi}]$ & + & + & - \\
\hline
\end{tabular}

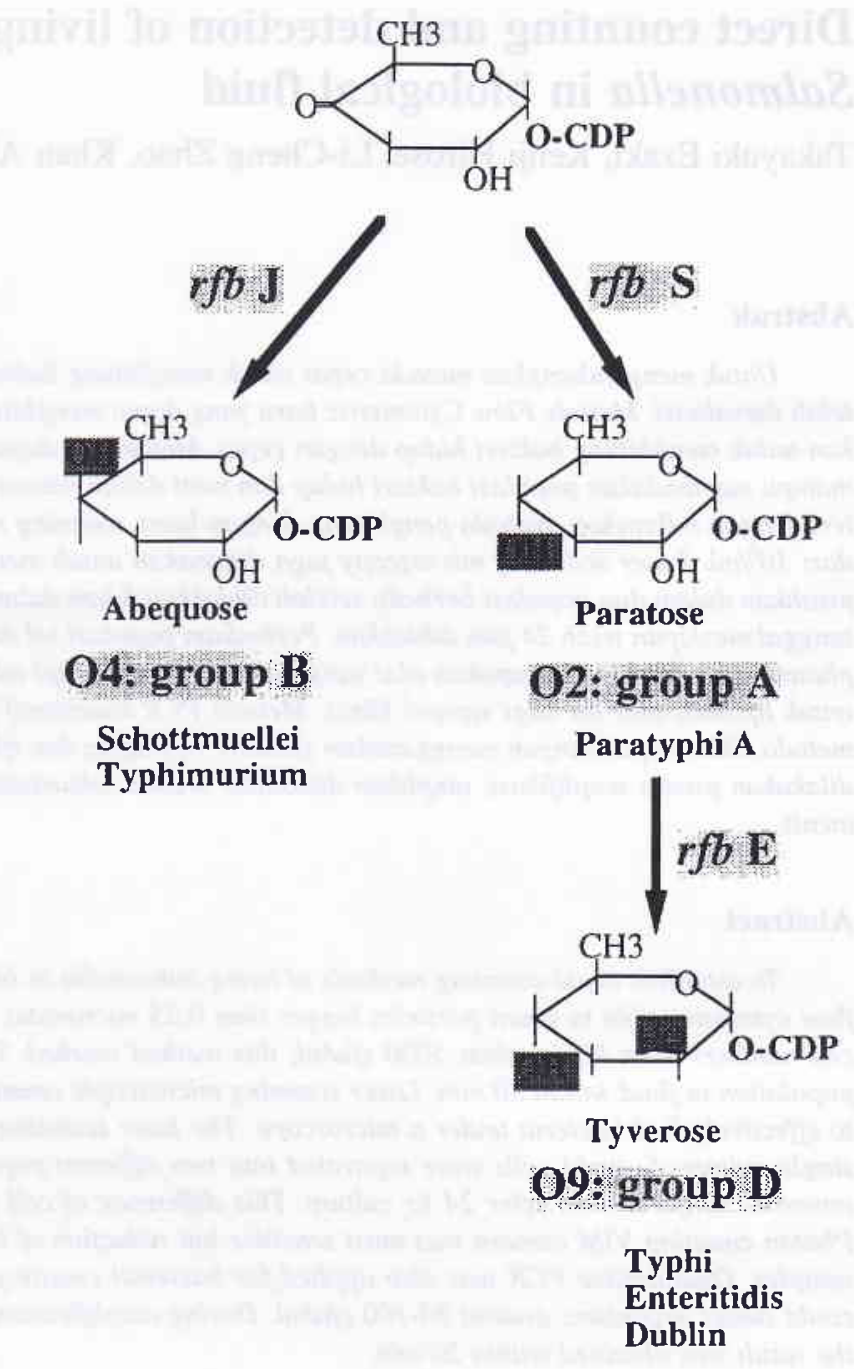

Figure 1. Primers for Salmonella $O$ antigen genes $\mathrm{rfbE}, \mathrm{rb} \mathrm{S}$, rbJ primers were designed for 0 serovar specific amplification.

rfbE-up: 5-ctt-ggg-agt-aat-ctt-gcc-3,

$\mathrm{rbE}$, rfb down: 5-tat-act-gcc-gta-ctg-cct-3

rfbS-up: 5-cct-act-tcg-aaa-gtc-gac-3,

rb-S-down: 5-cac-gaa-ttg-ata-tcg-cct-3

rfbJ-up: 5-aat-tgt-cag-tgg-ggc-ttc-3,

rbJ-down: 5-tcg-atg-aac-ctg-gca-tca-3

Primers to amplify, rfb (Figure 1), vipR (Figure 2), and fliC (Figure 3) genes were used. Sybergreen fluorescent were added in a PCR mixture to monitor PCR product during amplification process. Amplification was designed to finish within 15 min. using capillary light cycler (Aidaho Technology, Tokyo, Japan). 


\section{ViaB}

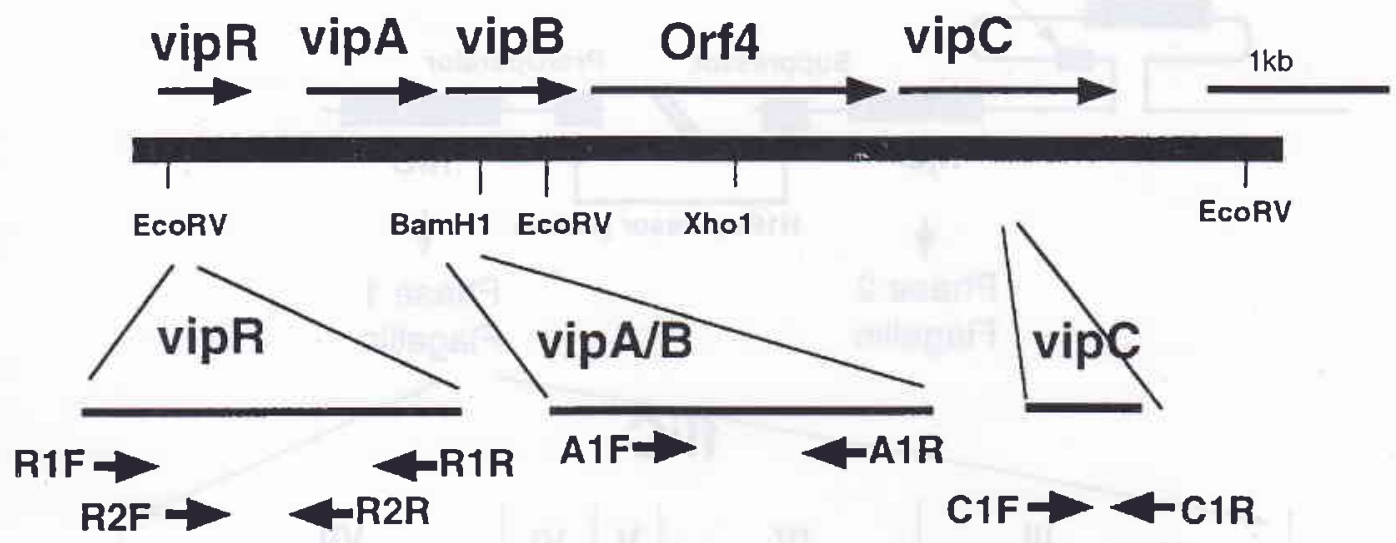

Figure 2. Primers for ViaB gene for S. typhi specific amplification.

$R 1 F: 5^{\prime}$-gtt-att-tca-gca-taa-gga-g-3',

R2F:5'-gtg-aac-cta-aat-cgc-tac-ag- $3^{\prime}$,

A1F:5'-gtt-ggg-ctt-cct-ctg-gca-gt-3',

vipC1F:5'-tca-atc-ttg-acc-agg-ctt-gc-3',
R1R:5'-act-tgt-ccg-tgt-ttt-act-c-3'

R2R:5'-ctt-cca-tac-cac-ttt-ccg-3'

A1R:5'-cac-atc-tga-ctg-ctc-agc-cg-3'

vipC1R:5'-taa-cga-ggc-tga-gag-agg-caa-t-3'
Table 2. Detection of Vi antigen gene from major Salmonella serovars

\begin{tabular}{lcccc}
\hline \multirow{2}{*}{$\begin{array}{l}\text { Salmonella } \\
\text { Serovar }\end{array}$} & \multicolumn{2}{l}{ Penotype } & Gene \\
\cline { 2 - 6 } & $\begin{array}{c}\text { Vi } \\
\text { antigen }\end{array}$ & vip A & vip C & vip R \\
\hline Group A & & & & \\
Paratyphi A GIFU 12697 & - & ND & ND & - \\
\hline Group B & & & & \\
Schottmuellei GIFU 12695 & - & ND & ND & - \\
Reading GIFU 12825 & - & ND & ND & - \\
Typhimurium GIFU 3163* & - & ND & ND & - \\
Essen GIFU 12814 & - & ND & ND & - \\
\hline Group C & & & & \\
Paratyphi C GIFU 12823 & Vi & + & + & + \\
Choleraesuis GIFU 2919 & - & - & - & - \\
Oranienburg GIFU 12698 & - & ND & ND & - \\
Newport GIFU 12817 & - & ND & ND & - \\
Muenchen GIFU 12789 & - & ND & ND & - \\
Thompson GIFU 12829 & - & ND & ND & - \\
\hline Group D & & & & \\
Typhi GIFU 2922* & Vi & + & + & + \\
Enteritidis GIFU 3161* & - & - & - & - \\
Dublin GIFU 13000 & Vi & + & + & - \\
Dublin GIFU 12699 & - & - & - & - \\
Gallinarum GIFU 12815 & - & ND & ND & - \\
Pulorum GIFU 12824 & - & ND & ND & - \\
Sendai GIFU 12826 & - & ND & ND & - \\
Panama GIFU 12822 & - & ND & ND & - \\
\hline Other serovars (E to V) & - & ND & ND & - \\
\hline Citrobacter freundii GIFU 12284 & + & - & + & - \\
Citrobacter freundii GIFU 2925 & - & ND & ND & - \\
\hline & & & & \\
\hline
\end{tabular}

* Clinical strains of these serovars were also analiyzed.

Vip $R$ positive: 34 strains of serovar Typhi,

Vip $R$ negative: 25 strains of serovar Enteritidis, 15 strains of serovar Typhimurium
Table 3. Detection of fli $\mathrm{C}$ gene

\begin{tabular}{llcc}
\hline & Salmonella & \multicolumn{2}{c}{ fli C primers } \\
\cline { 2 - 4 } & Serovar & FC1/FC2 & 394EG/395F \\
\hline A & Paratyphi A & ND & + \\
B & Schottmuellei (Paratyphi B) & - & + \\
C & Typhimurium & - & + \\
C1 & Paratyphi C & - & + \\
D1 & Typhi & + & + \\
D1 & Enteritidis & + & + \\
D1 & Dublin & + & + \\
\hline
\end{tabular}

ND: no data

Table 4. Comparison of 4 different counting methods

\begin{tabular}{llll}
\hline Method & $\begin{array}{l}\text { Suitable } \\
\text { cell } \\
\text { number }\end{array}$ & $\begin{array}{l}\text { Time } \\
\text { required }\end{array}$ & Features \\
\hline $\begin{array}{l}\text { Single Cell } \\
\text { Flowcytometer }\end{array}$ & $>5000 \mathrm{cfu} / \mathrm{ml}$ & $<1 \mathrm{hr}$ & $\begin{array}{l}\text { Differentiation of Cell } \\
\text { population }\end{array}$ \\
$\begin{array}{l}\text { Confocal Laser } \\
\text { Scanning Microscopy }\end{array}$ & $>10^{6} \mathrm{cfu} / \mathrm{ml}$ & $<1 \mathrm{hr}$ & $\begin{array}{l}\text { Visualization of live } \\
\text { and dead cells }\end{array}$ \\
$\begin{array}{l}\text { Photon Counting } \\
\text { VIM Camera }\end{array}$ & $>100 \mathrm{cfu} / \mathrm{ml}$ & $1 \mathrm{hr}-2 \mathrm{hr}$ & $\begin{array}{l}\text { Sensitive, High back- } \\
\text { ground }\end{array}$ \\
Light Cycler & $>10 \mathrm{clu} / \mathrm{ml}$ & $<30 \mathrm{~min}$. & $\begin{array}{l}\text { Sensitive, Real Time } \\
\text { Monitor of Amplicons }\end{array}$ \\
\hline
\end{tabular}




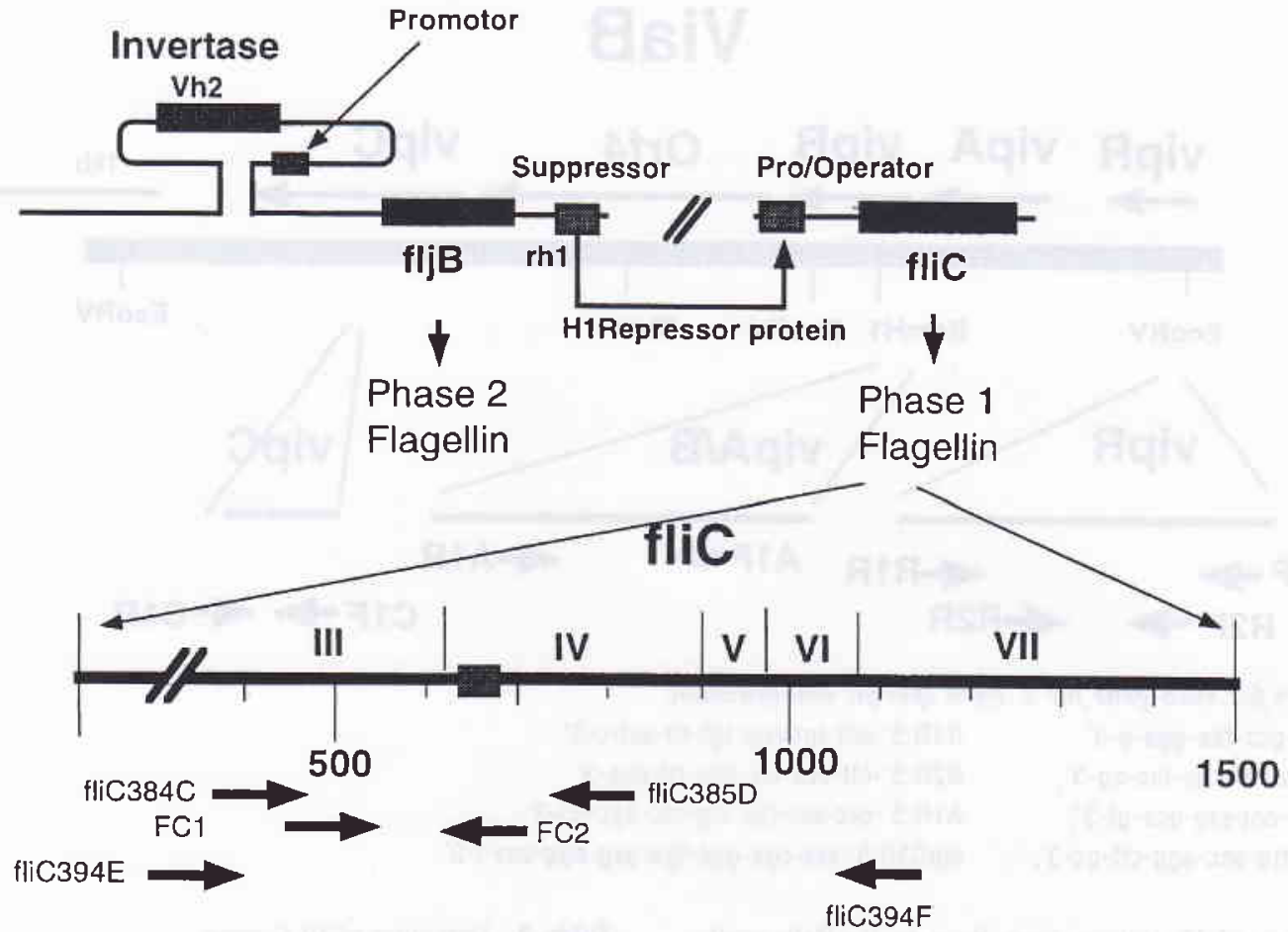

Figure 3. fliC gene amplification for Salmonella flagellar specific amplification.

FC1:5'-tga-tct-ctt-taa-gac-cac-cta-3', 384A:5'-gtg-cca-acg-acg-gtg-aaa-ct-3', 369A:5-aac-aac-ctg-cag-ctg-gtg-3,

384C:5'-gtg-cca-acg-acg-gtg-aaa-ct-3', 394E:5-tgt-atc-cgg-cca-gac-tca-gtt-3',
FC2:5'-aca-tcc-gtc-gcg-cca-gtg-gc-3 $384 \mathrm{~B}: 5^{\prime}-\mathrm{ctg}-\mathrm{c}(\mathrm{a} / \mathrm{t})(\mathrm{a} / \mathrm{t})-\mathrm{a}(\mathrm{ag}) \mathrm{c}-\mathrm{cac}-\mathrm{cat}-\mathrm{ca}-3^{\prime}$ 369B:5-atc-ttc-gat-acg-gct-acg-3 $385 \mathrm{D}: 5^{\prime}-\mathrm{ctg}-\mathrm{c}(\mathrm{a} / \mathrm{t})(\mathrm{a} / \mathrm{t})-\mathrm{a}(\mathrm{ag}) \mathrm{c}-\mathrm{cac}-\mathrm{cat}-\mathrm{ca}-3^{\prime}$ $395 F: 5^{\prime}-g c(a t)-(g a)$ (ga)g-taa-gt(tc)-tta-cc-3

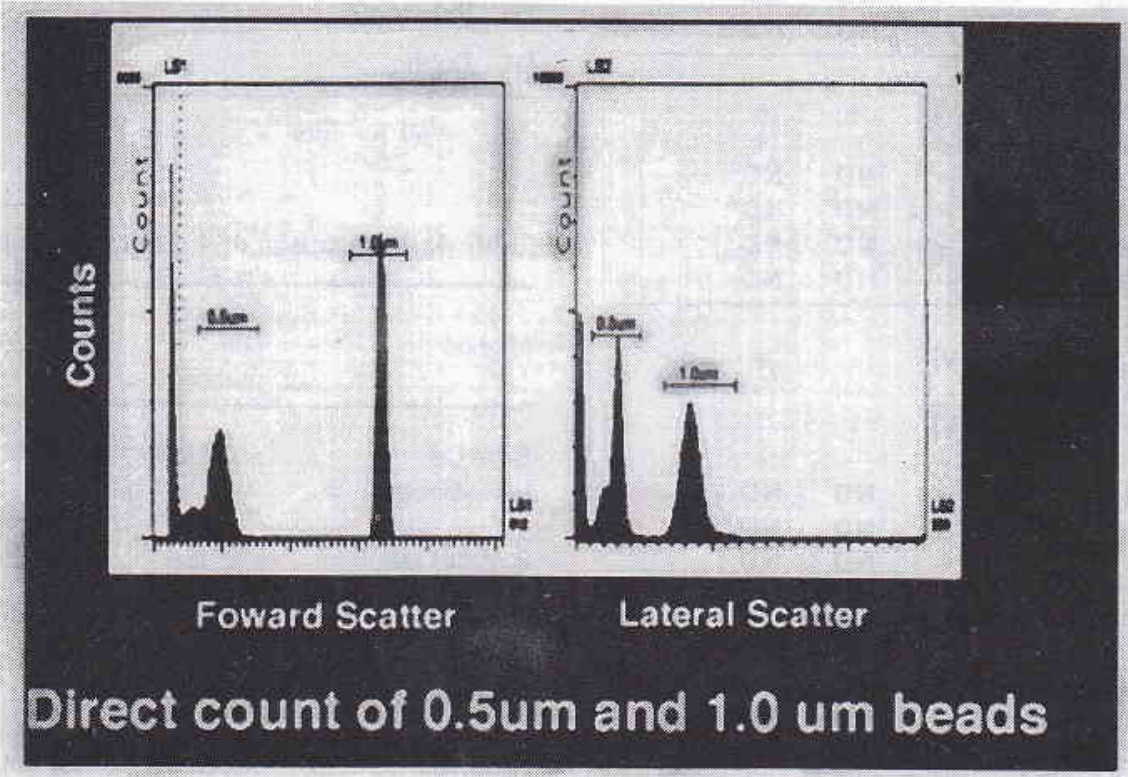

Figure 4. Counting $0.5 \mu \mathrm{m}$ and $1.0 \mu \mathrm{m}$ beads with a flowcytometer for bacterial counting. 


\section{RESULTS AND DISCUSSION}

Direct and rapid counting of living pathogenic bacteria in biological fluid is a final goal of this study. A new flowcytometric counting method was able to count particle bigger than $0.25 \mu \mathrm{m}$, while conventional flowcytometer only count particles bigger than $2 \mu \mathrm{m}^{2}$. Because sample flow on the surface of thin cover glass surface in a new flowcytometer. As in Figure $40.5 \mu \mathrm{m}$ and $1 \mu \mathrm{m}$ particle were clearly differentiated. The method was very rapid and simple and potential to be a routine counting method at clinical laboratories. However, number of bacteria to be counted should be higher than $5000 \mathrm{cfu} / \mathrm{ml}$. Theoretically it was possible to count bacterial lower than $1000 \mathrm{cfu} / \mathrm{ml}$, however, the signal was weak and no peak of fluorescent was visible when the organism was less than $1000 \mathrm{cfu} / \mathrm{ml}$. We applied this method to directly count bacteria in urine (data not shown). Data from direct plate counting method and flow cytometric counting were well correlated and mixed infection was predicted by their different fluorescent intensities because different fluorescent peaks were observed in case of mixed infection.

Laser scanning counting method is another technique directly count living pathogenic bacteria in clinical specimens. Combination of 2 or 3 emission lasers and development of computer graphic software evolutionalized his counting techniques. Live and dead cell staining fluorescent were used to count metabolic activities of $S$. typhi and survival of cell population during starvation and other stress. Sigma 38 deficient mutant created from $S$. typhi GIFU 10007 were very sensitive to $\mathrm{pH}$ stress, $\mathrm{H}_{2} \mathrm{O}_{2}$ stress, starvation in $\mathrm{M} 9$ cysteine medium. The dead cell and live cell population were quickly counted and quantitated within 30 minutes after staining. However, application of this method to count cells in clinical fluid might be limited because $10^{6} / \mathrm{ml}$ were usually required.

Recently, ChemSan system was introduced and was able to detect single cell on a filter. The system seems to be very simple and useful for real time counting of bacteria. However, The method cannot differentiate pathogenic bacteria.

Photon counting VIM camera ${ }^{8}$ was used to count cells emitting photons from the filter, because the cell on the filter was treated with alkaline phosphatase labeled antiserum. The method was the most sensitive among the above mentioned three methods. However, reducing the background photons emmitted from the filter was the biggest problem.
PCR amplification of pathogen specific genes are the most sensitive technique. However, the quantitative detection of living cells were not possible by this method. RT-PCR and quantitative amplification is a possible method to solve this problem. We selected several primers to differentiate Salmonella serovars. $\mathrm{rfb}$ gene $^{7}$, Vi regulatory gene $\mathrm{e}^{3-5}$ and flagellin gene $\mathrm{e}^{7,9}$ were selected for this purpose. Primers prepared from fliC gene of $S$. typhi could amplify most of Salmonella serovars. Amplification was performed by a light cycler and the fluorescent intensity of amplicons were monitored in each amplification cycle. The method was rapid because amplicons were quantitatively monitored during each amplification cycle. When the sample contained more than $10^{2} / \mathrm{ml}$ of bacteria, detection of $S$. typhi could be completed within $20 \mathrm{~min}$.

\section{REFERENCES}

1. Armstrong MY, Koziel H, Rose RM, Arena C , Richards FF. Indicators of Pneumocystis carinii viability in short-term cell culture. J Protozoology 1991; 38(6): 88S-90S

2. Davey HM, Kell DB. Flowcytometry and cell sorting of heterogeneous Microbial populations: the importance of singlecell analyses. Microbiol Review 1996; 60: 641-96.

3. HashimotoY, Li N, Yokoyama H, Ezaki T. Complete nucleotide sequence and molecular characterization of via $B$ region encoding Vi antigen in Salmonella typhi. J Bacteriol 1993; 175: 4456-65.

4. Hashimoto Y, Itho Y, et al. Development of nested PCR based on the ViaB sequence to detect Salmonella typhi. i Clin Microbiol 1995; 33: 775-7.

5. Hashimoto Y, Khan AQ, Ezaki T. Positive Autoregulation of vipR Expression in ViaB Region Encoded Vi Antigen of Salmonella typhi. J Bacteriol 1996; 178(5): 1430-6

6. Humphreys MJ, Allman R, Lloyd D. Determination of the viability of Trichomonas vaginalis using flow cytometry. Cytometry $1994 ; 15(4): 343-8$.

7. Itoh K, Hirose, Ezaki T. Amplification of rfbE and fliC genes by polymerase chain reaction for identification and detection of Salmonella serovar Enteritidis, Dublin and GallinarumPullorum. Microbiol Immunol 1997; 41:791-4.

8. Masuko M, Hosoi S, Hayakawa T. Rapid detection and counting of single bacteria in a wide field using a photoncounting TV camera. FEMS Microbiol Lett 1991; 67(2): 231-8.

9. Selander RK, Li J, Nelson K. Evolutionary genetics of Salmonella enterica p2691-2690. In FC Neidhardt (eds). Escherichia coli and Salmonella. vol. 2 ASM Press Washington DC 1996 